\title{
Yeasts and Moulds in the Bovine Rumen
}

\author{
By A. LUND \\ Department of Microbiology and Microbial Ecology, Royal Veterinary and Agricultural \\ University, Copenhagen, Denmark
}

(Received 28 September 1973; revised 28 October 1973)

\begin{abstract}
SUMMAR Y
Only small numbers of fungi were found in the rumen fluid of cattle cultured on agar plates at $39^{\circ} \mathrm{C}$, the counts being up to 3500 yeast colonies $/ \mathrm{ml}$, with a similar number of mould colonies. However, considerably larger numbers of yeast colonies appeared on plates incubated at $25^{\circ} \mathrm{C}$. Nine species of yeasts were isolated belonging to Candida (including corresponding species of Pichia), Trichosporon, Torulopsis, Kluyveromyces, Saccharomycopsis, and Hansenula. The predominating species were Candida krusei, Trichosporon cutaneum and Trichosporon capitatum. The most common moulds were members of the Mucoraceae, of which Absidia corymbifera, A. ramosa, and Mucor pusillus were identified. Aspergillus fumigatus was isolated frequently. The fungal content of rumen fluid seemed to be dependent on the diet of the animal, and no particular fungal flora could be associated with the rumen per se. The predominating Candida krusei, and also the rarely-isolated species Torulopsis pintolopesii and Kluyveromyces bulgaricus, could reproduce under anaerobic conditions in vitro, but another commonly occurring yeast, Trichosporon capitatum, was unable to grow under the same conditions. The majority of yeast cells were obviously destroyed during passage through the alimentary tract, whereas large quantities of moulds could be excreted in a viable state.
\end{abstract}

\section{INTRODUCTION}

Yeasts were observed in the rumen contents of ruminants by Klein \& Müller (I94I) and by Rolle \& Kolb (I955). Ingram \& McGaughey (I948) and van der Westhuisen, Oxford \& Quin (1950) isolated 'Candida-like organisms' and 'yeast-like organisms', respectively, from the rumen of sheep. Clarke (1960), Clarke \& di Menna (I96I) and MunchPetersen (I963) have given information on the yeast flora in the rumens of cows and sheep. They isolated species of Candida (albicans, tropicalis, krusei, rugosa, parapsilosis) and Trichosporon (cutaneum, sericeum) by plating at $39^{\circ} \mathrm{C}$.

Clarke \& di Menna (196I) found viable counts of from 80 to I3000 yeast colonies/g rumen content of cows, and Munch-Petersen (1963) reported a similar variation in the numbers of yeasts, generally finding about 1000 colonies $/ \mathrm{ml}$ rumen content of sheep. Smith (1965) found an average of about 300 yeast cells/g rumen content of oxen.

As regards moulds in the rumen, van der Westhuisen, Oxford \& Quin (1950) isolated Mucor sp. from the rumen contents of sheep, and Holtenius \& Nielsen (1957) found that Mucoraceae were predominant. They isolated Absidia ramosa and in addition Geotrichum candidum and a Fusarium strain, and reported (though with some uncertainty) that the number of moulds was 20 to $100 / \mathrm{ml}$ rumen fluid. Sivers $(1962 a, b)$ stated that the total number of fungi varied from several hundred to 20000 colonies $/ \mathrm{ml}$ rumen fluid of cattle, and that species of Absidia (corymbifera, ramosa), Mucor (pusillus, circinelloides, hiemalis), and Rhizopus (oryzae) were the moulds most frequently found. Bilai \& Pidoplichko (1962) 
also reported that the most common moulds in the rumen fluid of cows were species of Absidia and Mucor. Brewer \& Taylor (1969) counted about 100 to 500 fungal colonies/ml rumen fluid of sheep and isolated Aspergillus fumigatus. Brewer, Duncan \& Taylor (1972) isolated Mucor rouxii and counted about 100 to 1000 colonies $/ \mathrm{ml}$ rumen fluid of sheep.

Investigations dealing with yeasts in the lower alimentary tract can be mentioned here for purposes of comparison (Parle, I957; van Uden \& Carmo Sousa, 1957a; van Uden, Carmo Sousa \& Farinha, I958; Soneda, I959; Batista, de Vasconcelos, Fishman \& Staib, I96I ; Saëz, I963; Smith, 1965). The species of Candida and Trichosporon isolated were similar to those found in the rumen contents. In addition, other yeasts, both sporogenous and asporogenous, were found. Varying numbers of yeasts were found in samples of faeces from various ruminants in zoological gardens, up to many thousands per gram being counted in cultures incubated at $30^{\circ} \mathrm{C}$ (Soneda, 1959). Averages of about 250 yeasts/g were counted in the caecal contents of oxen, and $<50$ yeasts/g faeces of oxen and sheep (Smith, 1965). The number of yeasts in the intestinal tracts of cattle, sheep and goats was reported to be $<1000 / g$ (Mehnert, 1965).

The moulds found in the intestinal tract and faeces of cattle contained types similar to those known from the rumen contents, species of Aspergillus, Absidia, Mucor, Rhizopus, Geotrichum (van Uden \& Carmo Sousa, I957b; Batista, de Vasconcelos, Fischman \& Staib, 196I).

The main purpose of the present work was to examine the yeasts in the rumen of cattle in order to establish their numbers and taxonomic positions, their dependence on various feeding-stuffs, and their growth under anaerobic conditions; however, the moulds which developed under the same cultural conditions were also included. The study forms part of a project on rumen microbiology under the auspices of the Danish Agricultural and Veterinary Research Council. A report on the bacterial flora in the rumen of cows on similar diets is in the press (Wolstrup, Jensen \& Jensen, 1974).

\section{METHODS}

The yeast content in 49 samples of rumen fluid of cattle was examined, and moulds which appeared on the same plates as the yeasts were also included.

The rumen fluid samples were taken from ten fistulated animals as described by Hungate (1950), and from two non-fistulated cows by a stomach tube. Usually two or three samples were taken from each animal at varying intervals, though 16 samples were taken from one cow. Samples were taken $4 \mathrm{~h}$ after the morning feed, except in the case of cows fed on grass where they were taken just before the evening milking. The feeds used are shown in Table I.

In order to find a possible correlation between the fungi content in the rumen fluid and in the feeds, I 6 samples of feed material or feed components were examined. Six faeces samples were included to ascertain whether viable fungi were excreted.

The samples of rumen fluid and the suspensions of feed material and faeces were treated in a Waring blender for $2 \mathrm{~min}$. Immediately after mixing, aerobic pour plates were made from dilutions $\mathrm{I}: \mathrm{IO}$ and $\mathrm{I}: \mathrm{I00}$, and from higher dilutions when necessary. The agar medium consisted of Io g glucose, $2 \mathrm{~g}$ peptone (Difco), $2 \mathrm{~g}$ yeast extract (Difco), $5 \mathrm{~g}$ ox gall, $20 \mathrm{~g}$ agar and $\mathrm{I} 1$ distilled water. Immediately before use, $30 \mathrm{mg}$ streptomycin sulphate and $30 \mathrm{mg}$ aureomycin were added per 1 (cf. dextrose-peptone-yeast extract agar described by Papavizas \& Davey, 1959). Five plates were prepared from each dilution, and after incubation for 3 to 4 days at 39 or $25^{\circ} \mathrm{C}$, the fungal colonies were counted and the 
Table I. Animal feeds

\begin{tabular}{|c|c|c|c|}
\hline & Feed & $\begin{array}{l}\text { No. of } \\
\text { animals* }\end{array}$ & $\begin{array}{l}\text { No. of } \\
\text { samples }\end{array}$ \\
\hline I & Grass & 2 & 4 \\
\hline II & Hay & 2 & 7 \\
\hline III & Rolled oats & 2 & 4 \\
\hline IV & Grass pellets & 2 & 5 \\
\hline V & $\begin{array}{l}\text { Grass pellets }+ \text { dried beet pulp with } \\
\text { molasses }+ \text { concentrate pellets }\end{array}$ & I & 16 \\
\hline VI & Grass silage $\dagger$ & $\mathbf{I}$ & 2 \\
\hline VII & Grass silage + concentrates $\dagger$ & I & 2 \\
\hline VIII & Beet-top silage + grass + concentrates & 3 & 6 \\
\hline IX & Beets + straw + molasses + concentrates & I & 3 \\
\hline
\end{tabular}

* One of the ten cows was given feeds I and VIII, and two heifers given feeds III and IV. The animals were on each feed for four weeks before the first sampling.

$\dagger$ The cows on feeds VI and VII did not thrive, and thus the conditions in the rumen were possibly abnormal.

numbers were recorded as the average per millilitre or gram of material. Finally, colonies were transferred to malt-extract agar slopes.

In addition, several samples of rumen fluid were examined for yeasts by means of enrichment cultures, $5 \mathrm{ml}$ (dilution $\mathrm{I}: \mathrm{IO}$ ) being transferred to $50 \mathrm{ml}$ of the above medium without agar. Five cultures were prepared from each sample and incubated at $39^{\circ} \mathrm{C}$ for 7 to 8 days. Plating was made on to the agar medium and, after incubation at $39{ }^{\circ} \mathrm{C}$, yeast colonies were transferred to malt-extract agar slopes.

In the experiments on anaerobic growth of some of the yeasts isolated, the method of Hungate (I950) for cultivation of strictly anaerobic bacteria was used. A medium consisting of $20 \mathrm{~g}$ glucose, $20 \mathrm{~g}$ peptone (Difco), $5 \mathrm{~g}$ yeast extract (Difco) and I 1 distilled water was filled into tubes ( $10 \mathrm{ml} /$ tube) and immediately before inoculation, $0.5 \mathrm{ml}$ of a solution containing $\mathrm{NaHCO}_{3}\left(10 \%\right.$, w/v), cysteine $\mathrm{HCl}\left(0.5 \%\right.$, w/v) and $\mathrm{Na}_{2} \mathrm{~S} .9 \mathrm{H}_{2} \mathrm{O}(0.5 \%$, w/v) was added to each tube. The tubes were inoculated with $0^{\circ} \mathrm{I} \mathrm{ml}$ yeast suspension (one loopful of a young agar culture suspended in $10 \mathrm{ml}$ distilled water) and were incubated at $39^{\circ} \mathrm{C}$. Both the preparation and the inoculation processes were carried out under strictly anaerobic conditions in an oxygen-free atmosphere. Immediately after inoculation and at intervals during the incubation period, pour-plates were made on malt-extract agar, and the colonies were counted after incubation at $39^{\circ} \mathrm{C}$.

\section{RESULTS}

\section{Yeasts and moulds in rumen fluid}

Yeasts. Table 2 shows that only small numbers of yeasts were found in rumen fluid, when counting was on agar plates incubated at $39^{\circ} \mathrm{C}$. Half the samples contained no, or only a few, yeasts. Rumen fluid of animals given feeds I to IV rarely contained more than Ioo yeasts $/ \mathrm{ml}$, while some samples from cows on feeds V to IX contained up to $3500 / \mathrm{ml}$.

The numbers could vary considerably in samples taken at different times from the same animal. The greatest number of samples was taken from a cow on feed V, and most of these contained no, or only a few, yeasts, but greater numbers (up to $3000 / \mathrm{ml}$ ) were sometimes found. The numbers of yeasts in the rumen fluids of a fistulated cow and two non-fistulated cows given the same diet were about the same, as shown in Table 3. Two samples, with a 9 day interval, were taken from each cow and the cultures were incubated at $39^{\circ} \mathrm{C}$. 
Table 2. Numbers of yeasts in rumen fluid; incubation $39^{\circ} \mathrm{C}$

\begin{tabular}{rccccc}
\multicolumn{5}{c}{ No. of samples in each of the following ranges:* } \\
Feeds & $0-$ IO & II-I00 & IOI-500 & 50 I-I000 & I00I-3500 \\
I & 3 & 0 & I & 0 & 0 \\
II & 5 & 2 & 0 & 0 & 0 \\
III & 4 & 0 & 0 & 0 & 0 \\
IV & 3 & 2 & 0 & 0 & 0 \\
V & IO & I & 2 & I & 2 \\
VI & 0 & 0 & I & I & 0 \\
VII & 0 & I & 0 & 1 & 0 \\
VIII & 0 & I & 0 & 3 & 2 \\
IX & 0 & I & 2 & 0 & 0 \\
& $*$
\end{tabular}

Table 3. Numbers of yeasts in rumen fluid of fistulated and non-fistulated cows given feed VIII; incubation $39^{\circ} \mathrm{C}$

$\begin{array}{lcc} & \text { No. of yeasts/ml rumen fluid } \\ \text { Fistulated cow } & \overbrace{\text { Sample I* }}^{\text {I* }} & \text { Samp } \\ \text { Non-fistulated cow } & 3500 & 600 \\ \text { Non-fistulated cow } & 600 & 50 \\ & 000\end{array}$

* Sample I was taken on 18 July 1972, and sample 2 on 27 July 1972.

Table 4. Numbers of yeasts in rumen fluid; incubation 25 and $39{ }^{\circ} \mathrm{C}$

\begin{tabular}{crr}
\multirow{2}{*}{ Feed } & \multicolumn{2}{c}{$\begin{array}{c}\text { No. of yeasts/ml rumen } \\
\text { fluid incubated at: }\end{array}$} \\
IV & \multicolumn{2}{c}{$\begin{array}{c}{ }^{\circ} \mathrm{C} \\
60\end{array}$} \\
& 100 & $3{ }^{\circ} \mathrm{C}$ \\
V & 500 & 0 \\
& 1000 & 80 \\
& $>1000$ & 7 \\
& 2000 & 0 \\
VIII & 4000 & 200 \\
& 22000 & 1500 \\
& 100 & 0 \\
& 7000 & 50 \\
& 10000 & 2000 \\
& 16000 & 600 \\
20000 & 3500 \\
& 130000 & 1000
\end{tabular}

Samples were taken on different days.

Table 4 shows that considerably more yeast colonies developed on plates incubated at $25^{\circ} \mathrm{C}$ than on corresponding plates at $39^{\circ} \mathrm{C}$.

From samples of the rumen fluids of animals on various diets, nine species belonging to Trichosporon, Candida (including corresponding species of Pichia), Torulopsis, Kluyveromyces, Saccharomycopsis, and Hansenula were isolated after incubation of cultures at $39^{\circ} \mathrm{C}$. Table 5 shows that Candida krusei, Trichosporon cutaneum, and Trichosporon capitatum 
Table 5. Yeasts isolated from rumen fluid*; incubation $39^{\circ} \mathrm{C}$

Feed

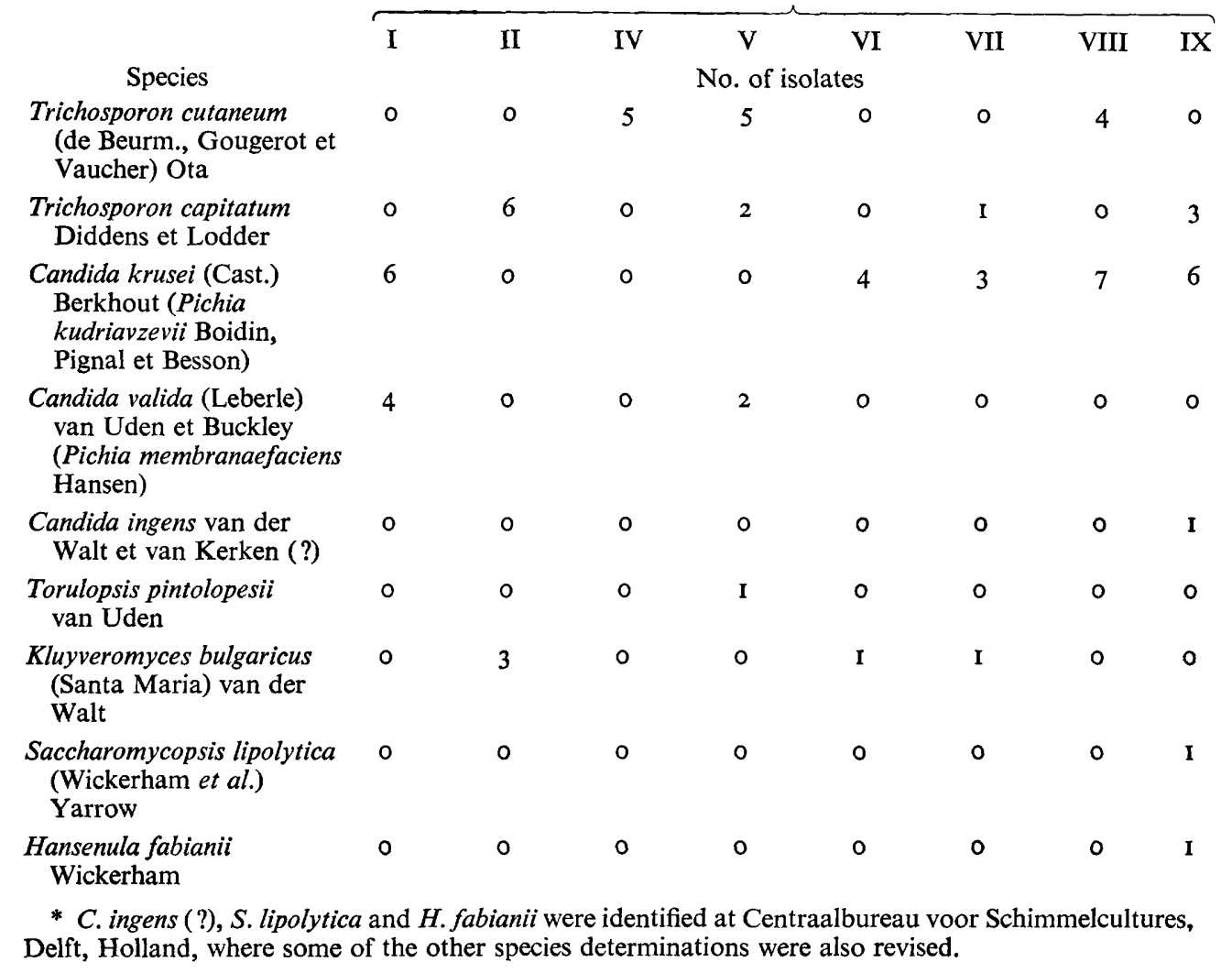

were the species found most frequently. These yeasts together represented 52 of the total of 67 isolates, and one or two of them were found in the rumen fluids of animals on all feeds. The remaining 15 isolates belonged to the other six species and, with the exception of Candida valida and Kluyveromyces bulgaricus, only a single isolate of each species was found.

Usually only one or sometimes two species, either Candida krusei, Trichosporon cutaneum or $T$. capitatum, appeared on platings of rumen fluid, and other yeasts were isolated only rarely. In enrichment cultures, $C$. krusei also developed, whereas Trichosporon spp. were found less frequently. On the other hand, $C$. valida and Kluyveromyces bulgaricus were isolated almost exclusively from enrichment cultures. Table 6 shows the yeasts isolated, partly by plating and partly by enrichment, from samples of rumen fluid incubated at $39{ }^{\circ} \mathrm{C}$.

Moulds. The numbers of mould colonies per millilitre of rumen fluid counted after incubation at $39^{\circ} \mathrm{C}$ are shown in Table 7 . Samples from animals on feeds I, IV, V and VIII contained small numbers of moulds, whereas those from animals on feeds II, III, VI, VII and IX could contain greater quantities. The moulds were primarily members of the Mucoraceae. Aspergillus was also common, while other moulds were found only rarely and then in insignificant numbers. Three species of Mucoraceae were identified, Absidia corymbifera, A. ramosa and Mucor pusillus, together with one species of Aspergillus, A. fumigatus. Table 8 shows that Absidia spp. and Aspergillus fumigatus were isolated from the rumen fluids of animals on all the diets, whereas $M$. pusillus was found in one sample only. 
Table 6. Yeasts isolated from rumen fluid by plating and enrichment; incubation $39{ }^{\circ} \mathrm{C}$

Species

Trichosporon cutaneum

Trichosporon capitatum

Candida krusei

(Pichia kudriavzevii)

Candida valida

(Pichia membranaefaciens)

Candida ingens (?)

Kluyveromyces bulgaricus

Saccharomycopsis lipolytica

Hansenula fabianii
No. of isolates

$\overbrace{\text { Platings Enrichment }}$

$\begin{array}{ll}7 & 0 \\ 9 & 2 \\ 9 & 8 \\ I & 5 \\ & \\ I & \\ 0 & 0 \\ I & 5 \\ 0 & 0 \\ & \end{array}$

Table 7. Numbers of moulds in rumen fluid; incubation $39^{\circ} \mathrm{C}$

\begin{tabular}{rccccc} 
Feed & \multicolumn{5}{c}{ No. of samples in each of the following ranges:* } \\
II & $0-10$ & II-200 & $201-500$ & 50 I-1000 & I00 I-4000 \\
II & 2 & 2 & 0 & 0 & 0 \\
III & 0 & 2 & 3 & 1 & I \\
IV & 0 & 0 & 0 & 1 & 3 \\
V & 5 & 0 & 0 & 0 & 0 \\
VI & I2 & 4 & 0 & 0 & 0 \\
VII & 0 & 0 & 2 & 0 & 0 \\
VIII & 0 & 1 & 0 & 1 & 0 \\
IX & 5 & 1 & 0 & 0 & 0 \\
& 0 & 0 & 2 & 0 & 1
\end{tabular}

* The ranges are expressed as the numbers of moulds/ml rumen fluid.

Table 8. Moulds isolated from rumen fluid; incubation $39{ }^{\circ} \mathrm{C}$

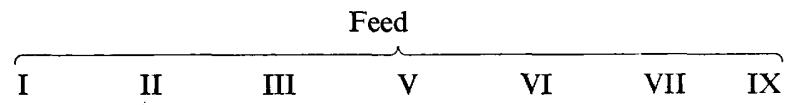

Species

Absidia corymbifera (Cohn)

Saccardo et Trotter

Absidia ramosa (Lindt)

Lendner

Mucor pusillus Lindt

Aspergillus fumigatus

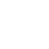

Fresenius

No. of isolates

The strains of Mucoraceae were identified at Centraalbureau voor Schimmelcultures, Baarn, Holland, and the isolates of Aspergillus by Dr P. Krogh, Department of Bacteriology and Hygiene, Royal Veterinary and Agricultural University, Copenhagen, Denmark. Although the number of Aspergillus identified was larger than that of Mucoraceae, the latter were the most common moulds in the rumen.

Yeasts and moulds in feeds. Most of the feeds contained no, or only a few, yeasts when cultured at $39^{\circ} \mathrm{C}$ (Table 9). However, larger numbers of yeasts were found in beets and concentrates (feed IX) and in beet-top silage (feed VIII).

The yeasts isolated from the feeds consisted of Candida krusei (concentrates, concentrate pellets, beet-top silage), Trichosporon sp. (concentrates), Kluyveromyces bulgaricus (beets), Candida valida (beets), and C. guilliermondii (concentrates, grass). 
Table 9. Numbers of yeasts and moulds in feeds; incubation $39{ }^{\circ} \mathrm{C}$

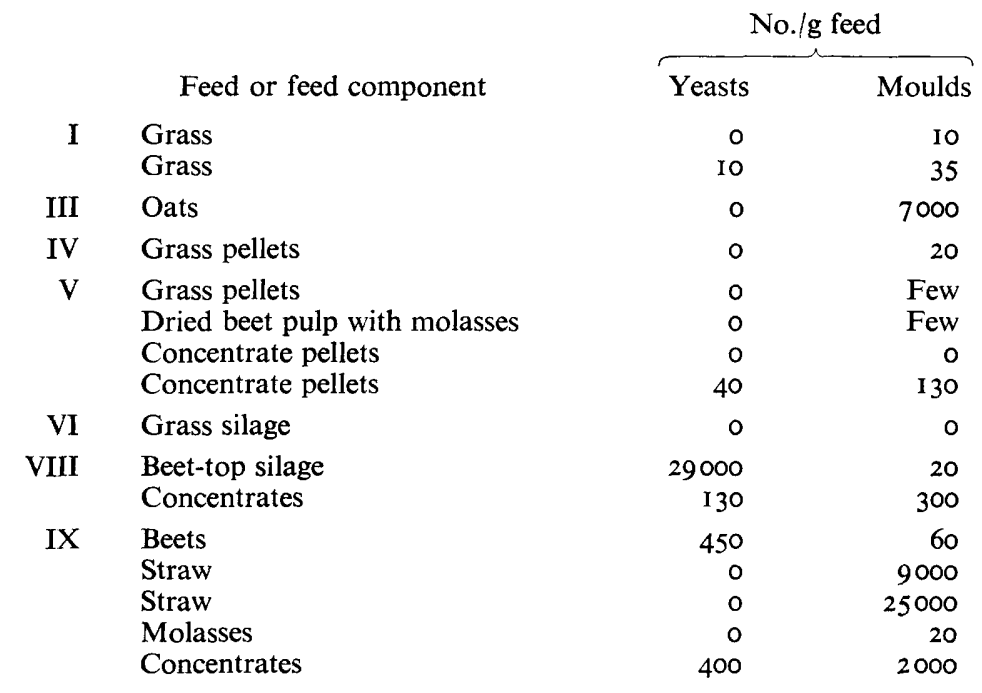

Table ro. Numbers of yeasts and moulds in faeces and simultaneous samples of rumen fluid; incubation $39^{\circ} \mathrm{C}$

$\begin{array}{rcrrr}\text { Feed } & \text { Yeasts } & \text { Moulds } & \overbrace{\text { Yeasts }}^{\text {No./g faeces }} & \text { Moulds } \\ \text { I } & 30 & 130 & 150 & 15 \\ \text { II } & 0 & >1000 & 0 & 1000 \\ \text { III } & 0 & 4000 & 0 & 1500 \\ \text { V } & 10 & 30 & 1500 & 30 \\ \text { VI } & 40 & >1000 & 500 & 300 \\ \text { VII } & \text { IO } & >1000 & 1000 & 200\end{array}$

Considerable quantities of moulds were present in oats (feed III) and straw and concentrates (feed IX) incubated at $39^{\circ} \mathrm{C}$, whereas other feeds examined contained no, or only small, numbers of moulds (Table 9). The predominating moulds belonged to Mucorales and Aspergillus.

Yeasts and moulds in faeces. Samples of faeces just dropped, and rumen fluid taken simultaneously from the animals, were examined in cultures incubated at $39{ }^{\circ} \mathrm{C}$. Table ro shows that the faeces samples contained only a few yeasts, even when a comparatively large number of yeasts was found in the rumen fluid samples. Candida krusei and Trichosporon capitatum were isolated from faeces.

A small number of moulds was found in the faeces of cows on feeds I and V, and simultaneously only insignificant quantities occurred in the samples of rumen fluid. A great many moulds were found in the faeces of animals on feeds II, III, VI and VII, and there were relatively large numbers in the rumen fluid of the same animals. The predominating moulds were members of Mucorales, though Aspergillus was quite common.

Anaerobic growth of yeasts isolated from rumen fluid. Two strains of each of the predominating species, Trichosporon capitatum and Candida krusei, were used, as well as one strain of Torulopsis pintolopesii and one of Kluyveromyces bulgaricus. Torulopsis pintolopesii 
Table I I. Anaerobic growth of yeasts isolated from rumen fluid at $39{ }^{\circ} \mathrm{C}$

For methods and media see text.

\begin{tabular}{|c|c|c|c|c|c|c|}
\hline \multirow{3}{*}{$\begin{array}{l}\text { Incubation } \\
\text { period } \\
\text { (days) }\end{array}$} & \multicolumn{6}{|c|}{ No. of yeasts $\times \mathrm{IO}^{-3}$} \\
\hline & \multicolumn{2}{|c|}{ Trichosporon capitatum } & \multicolumn{2}{|c|}{ Candida krusei } & \multirow{2}{*}{$\begin{array}{c}\text { Torulopsis } \\
\text { pintolopesii }\end{array}$} & \multirow{2}{*}{$\begin{array}{l}\text { Kluyvero- } \\
\text { myces } \\
\text { bulgaricus }\end{array}$} \\
\hline & Strain I & Strain 2 & Strain $\mathrm{I}$ & Strain 2 & & \\
\hline 0 & 4 & 57 & 4 & 200 & 20 & 100 \\
\hline 3 & 8 & 22 & 42 & I 1000 & 6I & 4000 \\
\hline 6 & 8 & 27 & NT & NT & 35 & 3000 \\
\hline 10 & 4 & 25 & 8000 & 4000 & 600 & 5000 \\
\hline
\end{tabular}

was examined since it belongs to the obligate saprophytes found in warm-blooded animals (van Uden et al. 1958) and $K$. bulgaricus was examined because this and other species of Kluyveromyces have been isolated from milk products (van der Walt, 1970). Table I I shows that no growth of Trichosporon capitatum took place. Either the yeast number remained constant during the experimental period of ten days, or it became reduced. On the other hand, distinct reproduction was found in Candida krusei, Torulopsis pintolopesii and Kluyveromyces bulgaricus.

\section{DISCUSSION}

The predominating yeasts in rumen fluid in the present investigation, Candida krusei and Trichosporon spp., were also among the yeasts isolated by Clarke \& di Menna (196r) and Munch-Petersen (1963). The considerable variation in yeast numbers found by those authors was also observed in the present study, though the maximum number was smaller.

While some of the yeasts isolated, such as the commonly occurring Candida krusei, were able to reproduce under anaerobic conditions at $39^{\circ} \mathrm{C}$ in vitro, no growth of the frequently occurring Trichosporon capitatum could be found under the same conditions. Krogh (196I) reported that vigorous growth of C. krusei and C. tropicalis took place in the rumen of sheep fed on hay with excess of sucrose, and Clarke \& di Menna (I96I) interpreted the yeasts isolated from rumen fluid of cows after incubation of cultures at $39^{\circ} \mathrm{C}$ as true rumen inhabitants since they were not found in the fodder of the animals. On the other hand, Rolle \& Kolb (1955) presumed that yeasts were introduced into the rumen with the fodder, and that they could be considered as occasional transients. MunchPetersen (1963) did not find any growth of sheep-rumen yeasts on agar plates incubated anaerobically at $39^{\circ} \mathrm{C}$, and yeasts were reported by Mehnert (1965) and Gedek (1968) as being unable to reproduce in the forestomachs of ruminants.

It is probable that the reproduction of yeasts in the rumen is rather limited and the majority of the yeasts are introduced with the fodder. This is supported by the observation that Trichosporon capitatum was frequently present in great numbers in rumen fluid although it was unable to grow under anaerobic conditions in vitro, and by the finding of a great many yeasts in the rumen which were unable to grow on agar plates at $39^{\circ} \mathrm{C}$. The considerable variation in the number of yeasts occurring in rumen fluid perhaps indicates the lack of any particular yeast flora of the rumen.

Clarke \& di Menna (1961) and Munch-Petersen (1963) did not find yeasts in fodder cultured at $39^{\circ} \mathrm{C}$. However, this corresponds to the finding of no, or only small quantities of, yeasts in the majority of samples of rumen fluid of animals on feeds I to V. Many 
yeasts were found in beet-top silage (feed VIII) and in beets and concentrates (feed IX), and most of the samples of the rumen fluid of cows on these diets contained relatively large numbers of yeasts. However, in spite of the presence of quite large numbers of yeasts in the rumen of cows on feeds VI and VII no yeasts were found in" grass silage. The cows fed on grass silage did not thrive and thus the conditions in the rumen were possibly abnormal. Yeasts were found in remnants of food and water from feeding and drinking troughs and this could contribute to the introduction of yeasts into the rumen.

Clarke \& di Menna (196I) reported a difference in the yeast flora dependent on the diet. The rumen fluid of cows fed on clover hay contained only non-fermenting species, while fermenting species were also present in the rumen fluid of cows fed with fresh clover. In the present study, mostly non-fermenting species were isolated from the rumen fluid of animals fed on dried fodder (feeds II, IV, and V), while fermenting species seemed to predominate in the rumen fluid of cows fed on fresh material (feeds I, and VI to IX).

The most common members of Mucoraceae in rumen fluid were species of Absidia, which were also among the moulds found most frequently in previous investigations (Bilai \& Pidoplichko, 1962; Sivers, 1962 b). In addition, Aspergillus fumigatus was found frequently; this species has also been isolated previously from rumen fluid (Brewer \& Taylor, 1969).

Considerable quantities of moulds were found in oats (feed III) and straw and concentrates (feed IX), and the rumen fluid of animals on these diets also contained a large number of moulds. Only a few moulds were found in other feeds examined, and the rumen fluid of animals on those diets contained only a few moulds. However, in the rumen fluid of cows fed on grass silage (feeds VI and VII) rather large quantities of moulds were found although there were no moulds in the feed material.

The author is grateful to Professor V. Jensen and Dr J. Wolstrup for valuable advice and help, to Dr P. Krogh for identification of Aspergillus strains, and to Dr J. Bodenhoff for revision of some of the yeast determinations. The able technical assistance of Miss D. Rasmussen and Mrs L. Lülloff is acknowledged.

The samples were procured from the National Experimental Farm 'Trollesminde', Hillerød, and the Veterinary Serum Laboratory, Copenhagen, and the work was supported by a grant from the Danish Agricultural and Veterinary Research Council.

\section{REFERENCES}

Batista, A. C., de Vasconcelos, C. T., Fischman, O. \& Staib, F. (I96i). Fungos leveduriformes e filamentosos de fezes de bovinos, no Recife. Instituto de Micologia, Universidade do Recife. Publiacão No. 325 , pp. I-27.

Bilai, V. J. \& Pidoplichko, N. M. (1962). On the microflora of the rumen of cows suffering from chronic hematuria. Microbiologiĕnÿ Zhurnal (Kiev) 24, 7-8.

Brewer, D., Duncan, J. M. \& TAYlor, A. (1972). Ovine ill-thrift in Nova Scotia. IV. The survival at low oxygen partial pressure of fungi isolated from the contents of the ovine rumen. Canadian Journal of Microbiology I8, I I I9-I 128.

Brewer, D. \& TAYLor, A. (1969). Aspergillus fumigatus and Sporormia minima isolated from the rumen of sheep. Journal of General Microbiology 59, I37-139.

ClARKe, R. T. J. (I960). Rumen Candida species and bovine mastitis. New Zealand Veterinary Journal 8 , 79.

Clarke, R. T. J. \& di Menna, M. E. (I96I). Yeasts from the bovine rumen. Journal of General Microbiology 25, $113-117$.

GEDEK, B. (1968). Hefen als Krankheitserreger bei Tieren. (Infektionskrankheiten und ihre Erreger. Eine Sammlung von Monographien Band 7). Jena: Gustav Fischer. 
Holtenius, P. \& NIELSEN, N. (1957). On the occurrence of nitrate and nitrite reducing fungi in the rumen of sheep. Nordisk veterinermedicin $9,210-213$.

Hungate, R. E. (1950). The anaerobic mesophilic cellulolytic bacteria. Bacteriological Reviews 14, I-49.

IngRAM, M. \& MCGAUGhey, C. A. (1948). Microflora of the rumen of the sheep. Nature, London 162, 533.

Klein, W. \& MülleR, R. (194I). Das Eiweissminimum, die zymogene Symbiose und die Erzeugung von Mikrobeneiweiss im Pansen aus Stickstoffverbindungen nicht eiweissartiger. Natur. Zeitschrift für Tierzüchtung und Züchtungsbiologie 48, 255-276.

KROGH, N. (196I). Studies on the alterations in the rumen fluid of sheep, especially concerning the microbial composition, when readily available carbohydrates are added to the food. IV. Identification of the Gram-positive flora developing during the feeding experiments. Acta veterinaria scandinavica 2, 357-374.

MeHNERT, B. (1965). Pilze des Verdauungstraktes. Ernährungsforschung 1o, 503-508.

MunCh-Petersen, E. (1963). Yeasts in the rumen of ruminants. Zentralblatt für Bakteriologie, Parasitenkunde, Infektionskrankheiten und Hygiene (Abteilung I) 189, 234-240.

Papavizas, G. C. \& DaveY, C. B. (1959). Evaluation of various media and antimicrobial agents for isolation of soil fungi. Soil Science 88, I1 2-1 17.

PARLE, J. N. (I957). Yeasts isolated from the mammalian alimentary tract. Journal of General Microbiology I7, 363-367.

Rolle, M. \& KolB, E. (1955). Über das Vorkommen von Hefen und hefeähnlichen Mikroorganismen im Pansen von Wiederkäuern. Zentralblatt für Bakteriologie, Parasitenkunde, Infektionskrankheiten und Hygiene (Abteilung I) 162, 304-309.

SAËz, H. (1963). Contribution à l'étude de la mycoflore intestinale des animaux sauvages en captivité. II. Levures isolées chez 77 jeunes mammifères. Révue de Mycologie 28, 52-61.

SIVERS, V. S. (1962a). Quantity of microscopic fungi in the rumen of cattle during winter and summer keep. Microbiologiěn̈̈ Zhurnal (Kiev) 24, 57-58.

Sivers, V. S. (1962 b). Fungi of the order Mucorales in the rumen of cattle. Microbiologienny Zhurnal (Kiev) 24, 19.

SмIтH, H.W. (1965). Observations on the flora of the alimentary tract of animals and factors affecting its composition. Journal of Pathology and Bacteriology 89, 95-122.

SonedA, M. (1959). Studies on animal-dung inhabiting yeasts. Nagaoa (Tokyo) 6, I-24.

van Uden, N. \& CARmo Sousa, L. Do (1957a). Yeasts from the bovine caecum. Journal of General Microbiology 16, 385-395.

van Uden, N., Carmo Sousa, L. Do (1957b). Fungos do género Aspergillus no tracto intestinal de bovinos e equideos. Boletim pecuário (Lisboa) 25, 33.

van Uden, N., Carmo Sousa, L. Do \& Farinha, M. (1958). On the intestinal yeast flora of horses, sheep. goats and swine. Journal of General Microbiology 19, 435-445.

VAN DER WALT, J. P. (1970). Kluyveromyces van der Walt emend. van der Walt. In The Yeasts, a Taxonomic Study, pp. 316-378. Edited by J. Lodder. Amsterdam and London: North-Holland Publishing.

VAN DER WESTHUISEN, G. C. A., OXFord, A. E. \& QUIN, J. I. (1950). Studies on the alimentary tract of Merino sheep in South Africa. XVI. On the identity of Schizosaccharomyces ovis. Part I. Some yeast-like organisms isolated from the rumen contents of sheep fed on a lucerne diet. Onderstepoort Journal of Veterinary Science and Animal Industry 24, I 19-124.

WolstruP, J., JeNSEN, V. \& JENSEN, K. (I974). The microflora and concentrations of volatile fatty acids in the rumen of cattle fed on single component rations. Acta veterinaria scandinavica $\mathbf{I 5}$ (in the Press). 